\title{
PEMIKIRAN EKONOMI IBNU QAYYIM TENTANG KONSEP TAS'IR
}

\author{
A. Rio Makkulau Wahyu \\ Institut Agama Islam Negeri (IAIN) Parepare \\ andi.rio51@yahoo.com
}

\begin{abstract}
Ibn Qayyim Al-Jauziyyah is an Islamic thinker who examines various issues which are meant in the economic field which are contained in his various works such as; in At-Thuruq Hukmiyah Fi As-Siyasati Asy-Syariyah. This book explains about a guideline of government in set a state policy. Ibnu Qayyim in his book divided pricing policy into 2 kinds those are fair pricing policy and legal and also unfair pricing policy and it is prohibited. This study is conducted by using library research method with the purposes to describe the thoughts of Ibn Qayyim about pricing policy. Analysis result showed that fair pricing policy in market mechanism has been main guidelines in every its transaction. Fair pricing by government is very suggested when the situation in market undergoes disorganisation thus make many bad impacts for trader, this the government's role as wilayatul hisbah in determining price in market for realising prosperity.
\end{abstract}

Keywords: Tas'ir, Wilayatul Hisbah, Justice

Abstrak: Ibnu Qayyim Al-Jauziyyah merupakan seorang pemikir Islam yang mengkaji berbagai persoalan termaksud bidang ekonomi yang tertuang dalam berbagai karyanya seperti yang termuat dalam kitab At-Thuruq Hukmiyah fi As-Siyasat Asy-Syariyah. Kitab tersebut menjelaskan mengenai sebuah pedoman pemerintah dalam menetapkan suatu kebijakan negara. Ibnu Qayyim dalam kitabnya ini membagi tas'ir menjadi dua bagian yakni tas'ir yang adil dan dihalalkan dan juga tas 'ir yang zalim dan diharamkan. Studi ini dilakukan dengan menggunakan jenis penelitian pustaka dengan tujuan untuk mendeskripsikan pemikiran Ibnu Qayyim tentang konsep tas 'ir. Hasil analisis didapatkan bahwa tas'ir yang adil dalam mekanisme pasar telah menjadi pegangan yang mendasar dalam setiap transaksinya. Penetapan harga yang adil oleh pemerintah sangat diajurkan ketika situasi dalam pasar mengalami kekacauan sehingga menimbulkan mudarat bagi pelaku pasar, inilah peran pemerintah sebagai wilayatul hisbah dalam menetapkan harga yang berlaku dalam pasar demi terwujudnya kemaslahatan.

Kata Kunci: Tas'ir, Wilayatul Hisbah, Keadilan, Ibnu Qayyim

\section{PENDAHULUAN}

\section{A. Latar Belakang Masalah}

Perkembangan Ekonomi Islam

menjadi sesuatu yang tidak dapat

dipisahkan dari perkembangan sejarah

Islam. Perkembangan ekonomi Islam yang ada sejak tahun $600 \mathrm{M}$ belum

dikenal masyarakat. Ekonomi Islam kurang mendapat perhatian yang baik, sebab masyarakat tidak mendapatkan informasi yang memadai. Pemikiran ekonomi Islam diawali sejak Muhammad 
saw. Kebijakan-kebijakan tersebut dijadikan pedoman oleh para khalifah dalam memutuskan masalah-masalah ekonomi. Al-Qur'an dan hadis digunakan sebagai dasar teori ekonomi oleh para khalifah juga digunakan oleh para pengikutnya dalam menata kehidupan ekonomi negara.

Ekonomi Islam menerapkan konsep kepemilikan tunggal yang bersumber dari Allah. Harta benda yang dimiliki oleh manusia merupakan titipan yang diberikan agar harta tersebut digunakan sesuai dengan petunjuk dan ketentuan yang disyariatkan Allah. Islam juga mengajarkan agar dalam melakukan kegiatan ekonomi ${ }^{1}$ seseorang harus menjunjung tinggi nilai keadilan, kesederhanaan, penghematan, dan kebaikan melalui konsep bagi kekayaan (zakat, infaq dan sedekah) dengan tujuan mewujudkan kemaslahatan di muka bumi dan meraih rida Allah swt. Sehingga kegiatan ekonomi di dalam Islam diyakini sebagai bagian dari manifestasi ibadah kepada Allah swt.

$\begin{array}{llr}\text { Perkembangan } & \text { ekonomi } & \text { Islam } \\ \text { adalah wujud } & \text { upaya } & \text { dalam } \\ \text { menerjemahkan Islam } & \text { sebagai } & \text { rahmatan }\end{array}$

lil' alamin, melalui proses yang panjang dan terus berkembang sesuai dengan perkembangan zaman. Kemunculan ekonomi Islam di era modern telah membuahkan hasil dengan banyak diwacanakan kembali ekonomi Islam di ranah bisnis modern. Hal ini merupakan sumbangsi pemikiran para ulama-ulama terdahulu yang mencurahkan segenap tenaga dan pikirannya untuk mengembangkan ekonomi yang bersifat rahmat yang ditemukan dan dikaji melalui pemikiran-pemikiran ulama terdahulu yang tertuang dalam buku-buku sejarah pemikiran ekonomi Islam.

Ilmu Ekonomi Islam sebagai sebuah studi ilmu pengetahuan modern muncul pada tahun $1970 \mathrm{M}$, tetapi pemikiran tentang ekonomi Islam muncul sejak Islam itu diturunkan melalui Nabi Muhammad, karena rujukan utama pemikiran ekonomi Islam adalah alQur'an dan hadis, maka pemikiran ekonomi ini munculnya juga bersamaan dengan diturunkannya al-Qur'an pada masa Rasulullah pada abad akhir $6 \mathrm{M}$ hingga awal abad $7 \mathrm{M}^{2}$

Setelah masa tersebut, ulama memberikan konstribusi karya pemikiran 
ekonomi. Karya-karya mereka sangat berbobot, yaitu memiliki dasar argumentasi religius dan intelektual yang kuat serta mayoritas didukung oleh fakta empiris pada waktu itu. Pemikiran ekonomi di kalangan pemikir Muslim banyak mengisi khazanah pemikiran ekonomi dunia pada masa Barat masih dalam kegelapan (dark age). Pada masa tersebut dunia Islam mengalami puncak kejayaan dalam berbagai bidang. ${ }^{3}$

Pemikiran ekonomi sebagai ilmu yang inheren dengan Ilmu Fikih bukan hal baru. Menurut Nejatullah Siddiqi, secara kronologis sejarah pemikiran ekonomi Islam dapat dikelompokkan kepada tiga periode. Pertama, yang ditandai dengan munculnya pemikir ekonomi Islam sampai tahun $450 \mathrm{H}$ seperti Abu Yusuf, Al-Syaibani, Abu Ubaid, Yahya ibn Umar, al-Mawardi dan Ibn Hazm. Kedua, periode intelektual, yang lahir pada periode ini antara lain AlGhazali, Ibnu Taymiyah dan Ibnu Khaldun. Ketiga, periode cendekiawan muslim seperti Syah Waliyullah, Muhammad Ibnu Abdul Wahab, Muhammad Abduh dan Muhammad Iqbal. Masa berikutnya adalah masa lahirnya banyak tokoh pemikir kontemporer yang pada akhirnya membentuk mazhab pemikiran dalam ekonomi Islam. ${ }^{4}$

Siddiqi mengklasifikasi periode ekonomi Islam menjadi 3:

Periode pertama merupakan pondasi (masa awal Islam-450 H/1058 M). Di antara para sarjana muslim yang hidup pada periode ini, yang masih berjumpa dengan para sahabat Nabi dan generasi tabi' in yang memeroleh referensi ajaran Islam yang autentik adalah Hasan Al-Basri, Zayd bin Ali, Abu Hanifah, Abu Yusuf, Muhammad bin hasan al Syaibani, Yahya bin Adam, Syafi'i, Abu Ubayd, Ahmad bin Hambal, Al-Kindi, Junayd Baghdadi, Al-Farabi, Ibnu Miskwayh, Ibnu Sina, dan Mawardi. ${ }^{5}$

Periode kedua (450-850 H/10581446 M) merupakan masa pemikiran ekonomi banyak dilatarbelakangi oleh menjamurnya korupsi dan dekadensi moral, melebarnya kesenjangan antara miskin dan kaya, meskipun secara umum kondisi perekonomian masyarakat Islam berada dalam taraf kemakmuran, tedapat pemikir-pemikir besar yang karyanya banyak dijadikan rujukan hingga kini. Di 
antaranya adalah al-Gazali, Nasiruddin Tutsi, Ibnu Taimiyah, Ibn Khaldun, alMagrizi, Abu Ishaq al-Syatibi, Abdul Qadir Jaelani, Ibnu Qayyim, Ibn Bajah, Ibnu Tufayl, Ibnu Rusyd, dan masih banyak lagi. ${ }^{6}$

Adapun pada periode ketiga (850$1350 \mathrm{H} /$ 1446-1932 M) yang merupakan masa kejayaan pemikiran. Terdapat beberapa pemikiran ekonomi yang berbobot selama dua ratus tahun terakhir, seperti yang tampak dalam karya dari Syah Waliullah, Muhammad bin Abdul Wahhab, Jamaluddin Al-Afgani, Muhammad Abduh, Ibn Nujaym, Ibn Abidin, Ahmad Sirhindi, dan Muhammad Iqbal. $^{7}$

Periode terakhir yakni periode kontemporer (1930-sekarang). Era ini merupakan masa kebangkitan intelektualitas di dunia Islam yang terbagi kedalam empat fase yakni:

Pertama, pertengahan 1930-an banyak muncul analisis masalah ekonomi sosial dari perspektif Islam sebagai wujud kepedulian terhadap dunia Islam secara umum dikuasai oleh negara-negara Barat.

Kedua, pada tahun 1970-an banyak pemikir ekonomi muslim yang berjuang keras mengembangkan aspek tertentu dari ilmu ekonomi Islam, terutama dari sisi moneter.

Ketiga, Perkembangan pemikiran ekonomi Islam selama satu setengah dekade terakhir menandai fase ketiga yang banyak berisi upaya-upaya praktikal operasional bagi realisasi perbankan tanpa bunga, baik di sektor publik maupun swasta.

Keempat, Pada saat ini perkembangan ekonomi Islam sedang menuju kepada sebuah pembahasan yang lebih integral dan kompherensif terhadap teori dan praktik ekonomi Islam.

Hal tersebut merupakan periode dalam perkembangan pemikiran ekonomi Islam dari masa awal Islam hingga masa sekarang yang terus mengalami perkembangan sesuai dengan kondisi dan kebutuhan dalam bermuamalah. Hal ini tidak lepas dari peran ulama-ulama terdahulu yang berijtihad demi kemaslahatan umat Islam khususnya dalam bidang ekonomi.

Fokus pengkajian diletakkan pada pemikiran ekonomi Islam di periode kedua yakni pemikiran Ibnu Qayyim alJauziyyah. Dalam berbagai literatur dan 
buku-buku sejarah pemikiran Islam kurang membahas pemikiran Ibnu Qayyim tentang ekonomi, bahkan hampir tidak ada yang mengkaji pemikiran ekonomi Ibnu Qayyim. Padahal Ibnu Qayyim dalam berbagai karya dan kitabnya banyak memuat persoalanpersoalan ekonomi yang relevan dengan kondisi saat sekarang ini.

Perwataatmadja menyebutkan bahwa di antara pemikir ekonomi pada masa khilafah Bani Abbasiyah II yang banyak memberikan konstribusi terhadap pengembangan ilmu ekonomi adalah Ibnu Qayyim al-Jauziyyah. Sehingga semakin jelas terlihat ketika pemikiran ekonomi yang telah disusun oleh ekonom muslim klasik seperti Ibnu Qayyim digali dan dikaji akan ditemukan hal yang menarik dan bernilai membangun suatu peradaban, misalnya saja ada hubungan pemikiran dan pengaruh pemikiran filsafat, termasuk ekonomi bagi para pemikir Barat modern dengan pemikiran yang dituangkan oleh Ibnu Qayyim dalam berbagai kitab karangannya. Ibnu Qayyim adalah murid Ibnu Taimiyah, seorang jurist dan pemikir sosial yang menguraikan banyak hal tentang pandangan gurunya dan menunjukkan suatu pandangan analitik dalam diskusi tentang masalah-masalah ekonomi. ${ }^{8}$

Ibnu Qayyim memiliki akhlak yang mulia, memiliki perangai lembut dalam pergaulan, mempunyai semangat tinggi, wawasan luas, temasuk orang besar dalam sisi karakteristik, kebaikan, keilmuwan, keutamaan dalam ibadah. alImam al-Hafizh Ibnu Katsir, salah satu muridnya berkata:

"Bacaan dan etikanya sangat baik, banyak berlemah lembut, tidak pernah hasad dan dengki kepada siapapun, tidak pula menyakiti dan mencela mereka. Secara umum kepribadiaannya dipenuhi oleh kebaikan dan akhlak yang mulia." 9

Argumen tersebut menandakan bahwa sikap dan tingkah laku Ibnu Qayyim termaksud dalam kategori tersebut hal ini diutarakan sendiri oleh muridnya yakni Ibnu Katsir.

Pemikiran ekonomi dari Ibnu Qayyim dalam berbagai masalah misalnya pengendalian harga, mekanisme pasar, pengawasan kegiatan ekonomi (alhisbah), kekayaan dan kemiskinan, bunga dan zakat, yang dijelaskan pada tempat 
yang berbeda dalam berbagai karyanya. Inti sari utama dalam pemikiran ekonominya adalah merealisasikan konsep kebajikan sosial, pelaksanaan keadilan dan penghapusan eksploitasi dalam kehidupan perekonomian.

Pada kajian kali ini akan difokuskan pada karya/kitab karangan Ibnu Qayyim yakni Al-Thuruq Hukmiyah fi al-Siyasati al-Syar'iyah yang merupakan karya Ibnu Qayyim yang diterbitkan di Dar al-Jil, Beirut pada tahun 1418 H/1998 M. Kitab tersebut menjelaskan mengenai sebuah pedoman dan panduan pemerintah dan politik Islam yang memaparkan beragam metode pengambilan hukum atau kebijakan untuk dijadikan panduan dan perbandingan dalam mengkaji persoalan bernegara, baik dalam bidang politik, sosial, kenegaraan maupun ekonomi saat sekarang ini yang pengkajiannya akan menekankan pada konsep tas'ir dalam kitab tersebut. Tas'ir secara etimologi yang berarti penetapan harga. Secara terminologi adalah penetapan harga standar pasar yang ditetapkan oleh pemerintah atau yang berwenang untuk disosialisasikan secara paksa kepada masyarakat dalam jual beli. ${ }^{10}$ Hal yang menarik dikaji dalam kitabnya, Ibnu Qayyim membagi tas'ir menjadi dua bagian yakni tas'ir yang adil dan dihalalkan dan juga tas 'ir yang zalim dan diharamkan. ${ }^{11}$ Ketika hal ini dikaitkan dengan sebuah hadis nabi, berdasarkan sababul wurud hadis ini yang diriwayatkan oleh Anas ra bahwa pada zaman Rasulullah di Madinah terjadi harga yang membumbung tinggi. Kemudian orang-orang berkata: "Wahai Rasulullah, harga begitu mahal, maka tetapkanlah harga bagi kami”. Lalu Rasulullah bersabda seperti hadis dibawah ini,

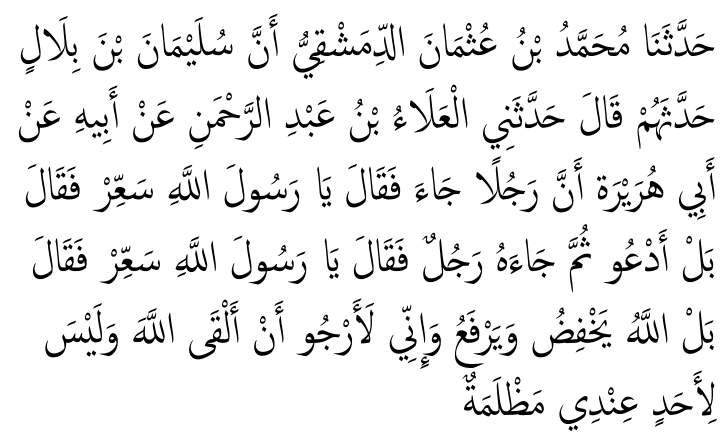

Artinya:

"Telah menceritakan kepada kami Muhammad bin Utsman Ad Dimasyqi bahwa Sulaiman bin Bilal telah menceritakan kepada mereka, ia berkata; telah menceritakan kepadaku Al 'Ala' bin Abdurrahman dari ayahnya dari Abu Hurairah bahwa seseorang datang dan berkata; wahai Rasulullah, tetapkanlah harga! Kemudian beliau berkata: "Allahlah yang menurunkan dan menaikkan, 
dan sesungguhnya aku berharap untuk bertemu dengan Allah sementara aku tidak memiliki dosa kezhaliman kepada seorangpun." (HR. Abu Daud No. 2993)

Kesimpulan dari hadis tersebut menyatakan bahwa tas'ir hukumnya adalah haram. Hal yang serupa juga dikatakan oleh Abu Yusuf mengenai persoalan penetapan harga/ tas'ir yakni $\mathrm{Abu}$ Yusuf menentang penguasa yang menetapkan harga atas alasan yang beliau sandarkan pada sunnah/hadis Rasulullah tersebut. $^{12}$ Hal ini memerlukan pengkajian dan diskusi secara mendalam ketika pemikiran ekonomi Ibnu Qayyim dibandingkan dengan hadis tersebut dan juga melihat kondisi ekonomi saat sekarang ini akan ditemukan suatu hal yang relevan yang nantinya dapat menjawab persoalan-persoalan ekonomi yang ada. Kehadiran Ibnu Qayyim dengan gagasan-gagasan cemerlangnya dalam pengkajian ekonomi menjadi menarik untuk diperbincangkan, disebabkan orientasi pemikirannya memliki ciri khas yang senantiasa relevan dengan konteks kekinian dan menjadi kajian ekonomi Islam sebagai salah satu cabang ilmu keislaman semakin aplikatif untuk diimplementasikan dalam kehidupan umat Islam.

Berdasarkan permasalahan ini, maka penulis tertarik untuk meneliti persoalan kajian pemikiran ekonomi klasik dalam rumusan judul yakni "Pemikiran Ekonomi Ibnu Qayyim tentang Konsep Tas'ir dalam kitab AlThuruq Hukmiyah fi al-Siyasati alSyariyah”.

\section{B. Metode Penelitian}

Studi ini dilakukan dengan menggunakan jenis penelitian pustaka (library research $)^{13}$ karena sumber data dalam penelitian ini adalah kitab karya Ibnu Qayyim, juga beberapa karya ilmiah yang membahas persoalan tas'ir, baik dalam bentuk buku maupun jurnal ilmiah dengan maksud studi komparatif. Sedangkan sifat penelitian ini adalah deskriptif kualitatif. Dengan sumber data yang berasal dari sumber data primer dan sekunder. Sumber data primer yakni kitab Kitab Al-Thuruq Hukmiyah fi al-Siyasati al-Syariyah karya Ibnu Qayyim alJauziyyah yang telah diterjemahkan kedalam bahasa Indonesia dengan judul Memutuskan Perkara. Sumber data sekunder yakni data-data yang diperoleh 
dari kepustakaan (buku, jurnal, atau referensi tertulis lainnya). Adapun tujuan penelitian ini untuk mendeskripsikan pemikiran Ibnu Qayyim Al-Jauziyyah terhadap tas'ir dalam kitab Kitab AlThuruq Hukmiyah fi al-Siyasati alSyariyah.

\section{PEMBAHASAN}

\section{A. Kerangka Teori}

\section{Tinjauan Umum tentang}

\section{Ekonomi Islam}

Ekonomi Islam dimaknai sebagai ilmu ekonomi yang dilaksanakan dalam kehidupan setiap saat bagi individu, kelompok, masyarakat maupun pemerintah dalam rangka pengorganisasian faktor produksi, distribusi dan pemanfaatan barang atau jasa yang dihasilkan termasuk mekanisme pasar dan penetapan harga dan tunduk dalam peraturan Islam. Secara normative, ekonomi Islam juga terkait dengan norma yang telah ada dalam ajaran dan sejarah masyarakat Islam dan menjadi panutan masyarakat Islam. ${ }^{14}$ Jadi, ekonomi Islam adalah perilaku dalam berekonomi yang harus sesuai dengan tuntutan syariah Islam dalam rangka mewujudkan dan menjaga maqashid syariah yakni menjaga agama, jiwa, akal, nasab dan harta yang orientasinya pada falah (keuntungan/ keseimbangan dunia dan akhirat).

Ekonomi Islam merupakan salah satu subsistem dalam suprasistem syariat Islam. Sebagai sebuah subsitem, sistem ekonomi Islam tegak dengan bertumpu pada empat landasan nilai, yaitu: ${ }^{15}$

a. Nilai Dasar

Hakikat kepemilikan atas segala sesuatu adalah milik Allah dan semuanya akan kembali kepada Allah sehingga dalam semua aktivitas ekonomi, baik produksi, konsumsi, dan distribusi harus senantiasa dikembalikan kepada aturanaturan yang telah ditetapkan baik dalam al-Qur'an dan hadis.

Keseimbangan dalam berbagai aspek kehidupan, Islam adalah agama yang mengajarkan keseimbangan dalam berbagai aktivitas dan dimensi kehidupan. Islam merupakan ajaran yang membawa risalah yang mengandung pesan moral untuk terciptanya tatanan kehidupan yang membawa kebaikan dan kesejahteraan bagi seluruh makhluk semesta (rahmatan lil alamin). 
Keadilan antar sesama makhluk. Keadilan adalah suatu terminologi yang mengandung arti adanya keseimbangan antar berbagai aspek kehidupan, baik antar aspek individu dan sosial, antara hak dan kewajiban, antara kepentingan dunia dan akhirat, antara kebutuhan jasmani dan rohani, dan sebagainya.

b. Landasan Instumental

Kewajiban zakat merupakan bentuk ibadah mahdhah sebagai bagian dari kesempurnaan rukun Islam yang berimplikasi sosial. Ketaatan seorang muslim tidak hanya menyangkut ibadah yang dimensi vertikal, tetapi juga harus diikuti dengan ibadah yang berdimensi horizontal. Hal itu mengandung arti bahwa Islam sebagai agama yang membawa kedamaian bagi seluruh alam (rahmatan lil alamin). Kesediaan seorang muslim untuk menyisihkan sebagian dari hartanya untuk zakat, infak, dan sedekah merupakan indikator keimanan dan ketakwaan terhadap Allah.

Larangan riba untuk menghindari eksploitasi antara satu kelompok terhadap kelompok lainnya dalam suatu aktivitas ekonomi yang dapat menimbulkan distorsi dalam perekonomian. Secara mikroekonomi praktik riba menimbulkan inefisiensi dalam alokasi sumber daya ekonomi sehingga menggangu produktivitas ekonomi. Sedangkan secara makroekonomi praktik riba menyebabkan ketidakseimbangan makroekonomi sehingga mendorong perekonomian ke jurang resesi ekonomi. Keadaan ini terjadi karena adanya ketidakseimbangan antara hak dan kewajiban antara pemilik modal dengan para pekerja. Kecenderungan pemilik modal berusaha mendapatkan keuntungan yang berlipat dari modal yang ditanamkan tanpa menghadapi resiko usaha yang mungkin timbul sehingga dengan kepemilikan modalnya akan mengeksploitasi untuk memberikan keuntungan yang besar. Secara akumulatif kaum pekerja/proletar dalam jumlah yang massal akan melakukan perlawanan secara fisik dan ekonomi melalui revolusi sosial untuk merebut sumber-sumber dan alat-alat ekonomi yang dikuasai kelompok kapitalis/borjuis dan akhirnya akan melahirkan masyarakat sosialis tanpa kelas/komunis. Hal itu merupakan gambaran secara singkat yang dikemukakan oleh Karl Marx dalam 
bukunya Das Kapital yang mengkritis sistem dan praktik ekonomi kapitalis yang berkembang melalui praktik ribawi. Islam tidak menghendaki adanya ketidakharmonisan dalam hubungan atau relasi antar individu dan kelompok dalam masyarakat. Islam mendorong semangat kerja sama saling menguntungkan dan saling menolong antar sesama individu sehingga tercipta masyarakat yang hidup dalam keharmonisan yang dibangun dari interaksi antar individu yang saling mendukung satu sama lain.

Kerja sama ekonomi, manusia dilahirkan berasal dari satu keturunan yakni merupakan anak cucu dari nabi Adam as. sehingga dengan kesadaran seperti itu melahirkan suatu semangat persaudaraan dan kerja sama antar umat manusia dengan dilandasi keimanan kepada Allah, sebagai pencipta seluruh umat manusia di muka bumi. Kerja sama ekonomi merupakan wujud dari kesadaran bahwa manusia secara fitrah adalah makhluk sosial yang eksistensinya sangat ditentukan interaksinya dengan lingkungan sekitarnya. Tidak dapat dibayangkan bila kehidupan seseorang yang terpisah dari akar social lingkungan masyarakat, bisa dipastikan bahwa akan menghadapi banyak kesulitan karena kehidupan seseorang tidak bisa terlepas dari campur tangan orang lain untuk memenuhi kebutuhan hidupnya seperti kebutuhan makan, pakaian, perumahan, transportasi dan lain sebagainya. Islam sangat menganjurkan agar seorang muslim selalu menjaga keharmonisan hubungan dengan orang lain dan mendorong semangat kerja sama dalam kebaikan bagi kehidupan yang lebih baik di dunia dan akhirat. Sengketa antara individu dan kelompok justru menjerumuskan manusia dalam jurang kesengsaraan hidup yang tidak akan pernah selesai kecuali kembali merajut tali kerja sama saling menolong antara sesama dalam masyarakat.

Islam sangat menghormati harkat dan martabat seorang manusia karena syariat Islam diturunkan untuk memberikan jaminan keselamatan atas kehormatan, kehidupan, dan kekayaan manusia. Dalam konteks kehidupan sosial, Islam mensyaratkan adanya jaminan sosial pada setiap individu dalam masyarakat. Peranan negara melalui baitul mal berfungsi untuk memberikan 
perlindungan dan kepastian bagian kebutuhan hidup semua lapisan masyarakat sehingga ada alokasi anggaran yang digunakan untuk kepentingan masyarakat miskin, bantuan bencana alam, jaminan bagi manula dan kepentingan sosial lain yang bersifat darurat dan mendesak. Dalam konteks kehidupan masyarakat, Islam menggariskan tentang mekanisme jaminan sosial dalam suatu keluarga melalui syariat harta waris agar tercipta jaminan kelangsungan hidup bagi suatu generasi.

Peranan negara, aturan dalam Islam menyangkut kehidupan baik dalam skala individu maupun sosial untuk terciptanya keseimbangan hidup manusia. Negara berperan untuk menjadi regulator agar aktivitas ekonomi berjalan secara benar dan mencegah terjadinya eksploitasi antara kelompok dalam masyarakat. Negara berperan agar penggunaan dan alokasi sumber daya ekonomi dilakukan secara efisien dan berorientasi kepada kemanfaatan bagi kesejahteraan masyarakat dan sekaligus untuk mencegah terjadinya konsentrasi dan monopoli kekayaan pada satu kelompok dalam masyarakat.

c. Landasan Normatif

Landasan akidah merupakan nilai fundamental Islam menjadi landasan dalam berbagai aktivitas termaksud ekonomi. Akidah Islam menjadi keyakinan dan sekaligus panduan bagi setiap muslim dalam melangkah sehingga aktivitas duniawi tidak hanya berorientasi untuk berkarya secara materi, tetapi memiliki nilai tambah berupa kemenangan dan keuntungan/ falah di akhirat.

Landasan akhlak ekonomi Islam merupakan bagian dari manifestasi akhlak Islam dalam bidang ekonomi. Jika melihat definisi akhlak yakni, dari sudut kebahasaan akhlak berasal dari bahasa Arab yaitu mashdar dari kata akhlaqa, yukhiqu, ikhlaqan, sesuai dengan timbangan/wazan majid af'ala, yuf'ilu, if'alan yang berarti al-sajiyah/watak, aith-thabi'ah/kelakuan, tabiat, watak dasar, al'adat/kebiasaan, kelaziman, almaru'ah/peradaban yang baik, dan aldin/agama. Namun akar kata akhlak yang secara linguistik kata akhlak merupakan isim jamid atau isim gahir mustaq yaitu 
isim yang tidak memiliki akar kata, melainkan kata tersebut memang sudah demikian adanya. Kata akhlaq adalah jamak dari kata khilqun atau khuluqun.

Landasan syariah yang meliputi sumber-sumber autentik dalam Islam untuk menjadi rujukan dalam pengambilan hukum dan dalil-dalil agama. Landasan syariat Islam meliputi Al-Qur'an, sunah, ijtihad yang meliputi kias, mashlahah mursalah, istihsan, istihab dan al- 'urf.

d. Landasan Filosofi

Sistem ekonomi Islam bersifat dinamik, penelitian dan pengembangannya berjalan terus seiring dengan perkembangan dan dinamika kehidupan manusia. Nilai-nilai fundamental Islam bersifat tetap, tetapi aplikasinya senantiasa lentur menghadapi dinamika perubahan yang terjadi. Fungsi al-Qur'an sebagai petunjuk dan pembeda bagi kehidupan manusia yang senantiasa relevan sampai akhir zaman.

\section{Teori Harga dalam Islam}

Islam merupakan satu-satunya agama yang mengedepankan prinsipprinsip yang meliputi segala aspek kehidupan manusia. Prinsip-prinsip ini bersifat fundamental dan universal yang berlaku untuk segala tempat dan zaman. Oleh karena itu, sistem ekonomi yang berdasarkan prinsip-prinsip ini tidak hanya menjabarkan kurva permintaan atau sebatas menetapkan kebijakan harga sehari-hari semata. Islam telah menawarkan kerangka kerja yang sedemikian luas untuk melakukan aktivitas ekonomi yang sama dan sedemikian luas untuk melakukan aktivitas ekonomi yang sama dan berkeadilan sehingga terjadilah kehidupan ekonomi yang berkeseimbangan di masyarakat. ${ }^{16}$

Abdul Mannan menyampaikan persoalan harga bahwa harga yang wajar bukanlah suatu konsesi, tetapi hak fundamental yang dikuatkan oleh hukum negara. Islam mengedepankan prinsip kooperatif dan persaingan yang sehat. Bukan persaingan monopoli seperti dalam sistem kapitalis. Akan tetapi persaingan sehat itu tidak berarti persaingan sempurna dalam pengertian modern, namun suatu persaingan yang bebas spekulasi, penimbunan, penyelundupan dan lainnya. Untuk menciptakan atmosfer kerja sama yang baik antara antara 
produsen dan konsumen dalam waktu yang lama, maka yang diperlukan adalah memacu semangat Islam, nilai-nilai, dan undang-undang bisnis yang Islami melalui proses pendidikan yang sistemik. Suatu negara yang berorientasi kepada nilai-nilai Islam harus menjamin agar keluhan masyarakat didengar, bahkan jika perlu dibentuk dan mengembangkan koperasi konsumen untuk meredam manipulasi harga dan monopoli.

Islam tentang harga tidak memperkenankan setiap jenis pengisapan, baik dari pihak produsen maupun konsumen. Untuk itu, perlu diadakan pembinaan denga perlindungan dan pengawasan negara demi keselarasan ketentuan-ketentuan keadilan sosial Islam dengan permintaan produsen. Tetapi menurut Abdul Mannan untuk menjaga tingkat harga kebutuhan pokok agar bisa dijangkau orang kebanyakan dan para pekerja, suatu negara harus menentukan kebijakan tindakan jangka pendek yang terdiri atas: ${ }^{17}$

a. Berkaitan dengan hasil bumi untuk perdagangan diupayakan agar para petani memperoleh harga layak dari hasilnya. b. Pembagian bahan pangan dan pengadaan barang konsumsi yang perlu disubsidi.

c. Menyelenggarakan musyawarah anatara konsumen dan produsen (pembeli dan penjual) di bawah perlindungan negara untuk mensosialisasikan kepada mereka bagaimana sistem transaksi yang Islami.

Adapun tindakan untuk jangka panjang yakni:

a. Perlu membentuk suatu badan yang dapat menetapkan harga yang layak dengan kekuasaan tertinggi terdiri dari wakil-wakil para produsen (penjual), konsumen (pembeli), ahli pemerintah, dan ahli hukum Islam.

b. Membentuk jaringan kooperatif konsumen (pembeli) di seluruh negeri dengan perlindungan negara.

c. Menyusun perencanaan konsumsi yang kompherensif dalam kerangka perencanaan negara.

\section{B. Hasil Analisis}

\section{Biografi Ibnu Qayyim Al-}

\section{Jauziyyah}

Ibnu Qayyim memiliki nama asli Muhammad Ibnu Abu Bakar. Ibnu 
Qayyim lahir di Damaskus pada tanggal 7 Safar 691 H dari seorang ayah yang bekerja sebagai kepala sekolah pada Madrasah Al Jawziyya. Latar belakang orang tuanya yang seorang pendidik ini yang membuat Ibnu Qayyim mendapatkan pendidikan Islam yang komprehensif semenjak kecil. Ibnu Qayyim banyak belajar dari ilmuwanilmuwan Islam terkenal seperti Shihaab $\mathrm{Al}^{‘}$ Abir, Taqiyyudin Sulaiman, Safiyyud Din Al-Hindi, dan 16 tahun didedikasikan untuk belajar dari Ibnu Tamiyyah. Oleh karena itu, buah pemikiran Ibnu Qayyim dipengaruhi oleh Ibnu Tamiyyah. Satu hal penting lainnya yang perlu dipahami adalah bahwa pada dasarnya Ibnu Qayyim bukan ilmuwan Islam yang fokus pada permasalahan ekonomi, melainkan lebih banyak kepada Tafsir al-Qur'an, Sunnah, dan permasalahan sosial dan politik. Pandangan Ibnu Qayyim mengenai permasalahan ekonomi sendiri muncul atas dasar kebutuhan pada masanya. $^{18}$

\section{Karya Ibnu Qayyim Al-Jauziyyah}

Adapun karya-karya Ibnu Qayyim diantaranya: Al-Ijtihad wa at-Taqlid, Ijtima 'al-Juyusy al-Islamiyah, Ahkam Ahl
adz-Dzimmah, Asma 'Muallafat Ibnu Taimiyyah, Ushul at-Tafsir, At-Thuruq Hukmiyah Fi As-Siyasati Asy-Syariyah, I'lam al-Muaqqi 'in 'an Rabb al-Alamin, Ighatsah al-Luhfan min Mashadir asySyaithan, dan karya-karya lainnya.

\section{Kandungan Isi Kitab al-Thuruq Hukmiyah fi al-Siyasati al-Syariyah}

Kitab tersebut diartikan sebagai pedoman hukum dalam pemerintahan dan politik Islam. Kitab karangan Ibnu Qayyim ini menjelaskan mengenai sebuah pedoman dan panduan pemerintah dan politik Islam yang memaparkan beragam metode pengambilan hukum atau kebijakan yang terjadi pada masa Rasulullah, sahabat, generasi tabi'in dan para khalifah untuk dijadikan panduan dan perbandingan bagi setiap ulama, penguasa, aktivis, wakil rakyat, penuntut ilmu dalam mengkaji persoalan bernegara baik dalam bidang politik, sosial, kenegaraan, bahkan ekonomi saat sekarang ini sehingga pemikiran Ibnu Qayyim sangat relevan dalam konteks kekinian khususnya persoalan ekonomi maupun terkait persoalan kebijakan pemerintah. 


\section{Pandangan Umum Pemikiran}

\section{Ekonomi Ibnu Qayyim Al-Jauziyyah}

Secara umum pemikiran Ibnu Qayyim tentang permasalahan ekonomi dapat digolongkan kedalam lima perkara utama yakni: Falsafah ekonomi Islam, perbandingan dan perbedaan antara kekayaan dan kemiskinan, kepentingan ekonomi zakat, bunga/ riba, mekanisme pasar dan penetapan harga.

Adapun uraian secara singkat mengenai pokok pikiran Ibnu Qayyim mengenai ekonomi Islam yakni: ${ }^{19}$

\section{a. Falsafah Ekonomi Islam}

Ibnu Qayyim berpandangan bahwa kehidupan itu adalah tes dan pengadilan bagi manusia. Cara manusia memenuhi semua kebutuhannya, mengatasi berbagai permasalahannya dan tentu akan ada reward dan punishment dari Allah (sebagaimana layaknya dalam sebuah pengadilan). Guna memenuhi kebutuhannya tersebut, manusia harus bekerja. Sebagai contohnya, setiap manusia butuh makan untuk bertahan hidup dan untuk memenuhinya manusia harus menanam, beternak ataupun mencari ikan dan semuanya itu termasuk ke dalam kegiatan ekonomi sejalan dengan sunnah Rasulullah. Ibnu Qayyim mengatakan bahwa dosa itu dapat memperburuk kehidupan seseorang. Oleh karena itu, agar kehidupan manusia menjadi baik, maka kepatuhan terhadap Allah merupakan hal yang mutlak. Jika manusia mengamalkan nilai-nilai Islam dalam kehidupannya maka akan timbul kepercayaan diri yang tinggi dan keamanan dalam masyarakat. Hal tersebut selanjutnya menjadi insentif bagi setiap orang untuk bekerja sama dalam berproduksi dan menjaga stabilitas kondisi ekonomi yang pada akhirnya akan mampu meningkatkan perekonomian. Selain itu, Ibnu Qayyim juga menyoroti tentang intervensi pemerintah dalam perekonomian tersebut dapat dibenarkan, yakni pada saat kepentingan orang banyak yang menjadi taruhannya.

b. Perbandingan dan perbedaan antara kekayaan dan kemiskinan

Kaya tidak selalu berarti anugerah ataupun hukuman melainkan sebuah ujian atau tes, hal yang serupa juga berlaku untuk miskin. Di tengah perdebatan mengenai yang lebih baik antara kaya dan miskin, Ibnu Qayyim memiliki pandangan yang sejalan dengan gurunya 
Ibnu Taimiyah, yakni bahwa kaya itu lebih baik dibandingkan miskin. Argumen utamanya adalah bahwa dengan kekayaan seseorang itu memiliki peluang yang lebih besar untuk beribadah seperti bersedekah, haji, membangun masjid, dan berbagai hal positif lainnya yang tentu akan sangat sulit dilakukan pada kondisi miskin.

c. Kepentingan ekonomi zakat

Terkait masalah zakat, Ibnu Qayyim memberikan penjelasan yang cukup detail mengenai alasan dibalik rate zakat yang berbeda-beda dan periode pembayaran zakat yang 1 tahun. Ibnu Qayyim memaparkan bahwa rate zakat akan semakin rendah jika penggunaan tenaga kerja semakin intensif. Zakat untuk barang temuan adalah yang terbesar yakni 20\% karena untuk mendapatkan barang temuan tersebut relatif menggunakan tenaga kerja yang relatif lebih sedikit. Alasan sawah tadah hujan dikenakan rate zakat sebesar $10 \%$, relatif lebih besar dibandingkan sawah irigasi sebesar 5\% karena pada sawah irigasi dibutuhkan tenaga untuk membuat saluran irigasi dan menyalurkannya ke sawah-sawah. Sehingga sawah irigasi lebih labor intensif dibandingkan dengan sawah tadah hujan. Selain itu Ibnu Qayyim juga menuliskan argument lainnya yang menyatakan bahwa beda tingkat pertumbuhan setiap barang yang mengakibatkan bedanya rate antar zakat. Terkait dengan periode pembayaran zakat, Ibnu Qayyim berpandangan bahwa penggunaan periode 1 tahun adalah sangat tepat mengingat bahwa hasil dari investasi kita pada umumnya baru akan terlihat setelah 1 tahun. Jika periode pembayaran zakat dibuat setiap bulan maka hal tersebut dapat menurunkan insentif para muzakki (pembayar zakat) untuk berproduksi lebih banyak lagi.

\section{d. Bunga/Riba}

Ibnu Qayyim membagi riba menjadi dua yakni, riba al-jali dan riba al-khafi. Riba al-jali terjadi jika pemberi pinjaman mengenakan tambahan biaya atau bunga atas pinjamannya. Praktik seperti ini merupakan hal yang lazim dilakukan pada masa jahiliyah. Riba al-khafi merupakan riba yang samar yang selanjutnya dibagi menjadi riba al-fadl (mengenakan jumlah tambahan ketika menukar barang yang sama) dan riba al-nasiyah (mengenakan jumlah tambahan ketika pembayaran 
tidak dilakukan pada saat yang sama mengintervensi, dan mensupervisi dengan transaksi). Merujuk kepada kegiatan ekonomi.

sunnah Rasulullah, semua ini hanya berlaku pada dua jenis kategori barang, yakni logam mulia dan bahan pangan. Ibnu Qayyim berpandangan bahwa menukar logam mulia dalam bentuk ornamen dengan logam mulia dalam bentuk uang dengan jumlah yang berbeda masih diperbolehkan mengingat ada biaya produksi dalam merubah logam mulia tersebut menjadi ornamen, tetapi menukar logam mulia dalam bentuk koin dengan logam mulia dalam bentuk uang dengan jumlah yang berbeda tidak diperbolehkan. Satu kata kunci disini adalah bahwa uang yang selanjutnya dijadikan sebagai alat ukur nilai dari suatu barang haruslah bersifat stabil dan nilainya tidak ditentukan oleh hal-hal eksternal lain.

e. Mekanisme pasar dan penetapan harga

Ibnu Qayyim berpandangan bahwa harga harus dibentuk oleh keseimbangan supply dan demand yang terbentuk di pasar. Selain itu, Ibnu Qayyim juga memandang penting peran dari al-hisbah, yakni sebuah lembaga untuk mengontrol, 


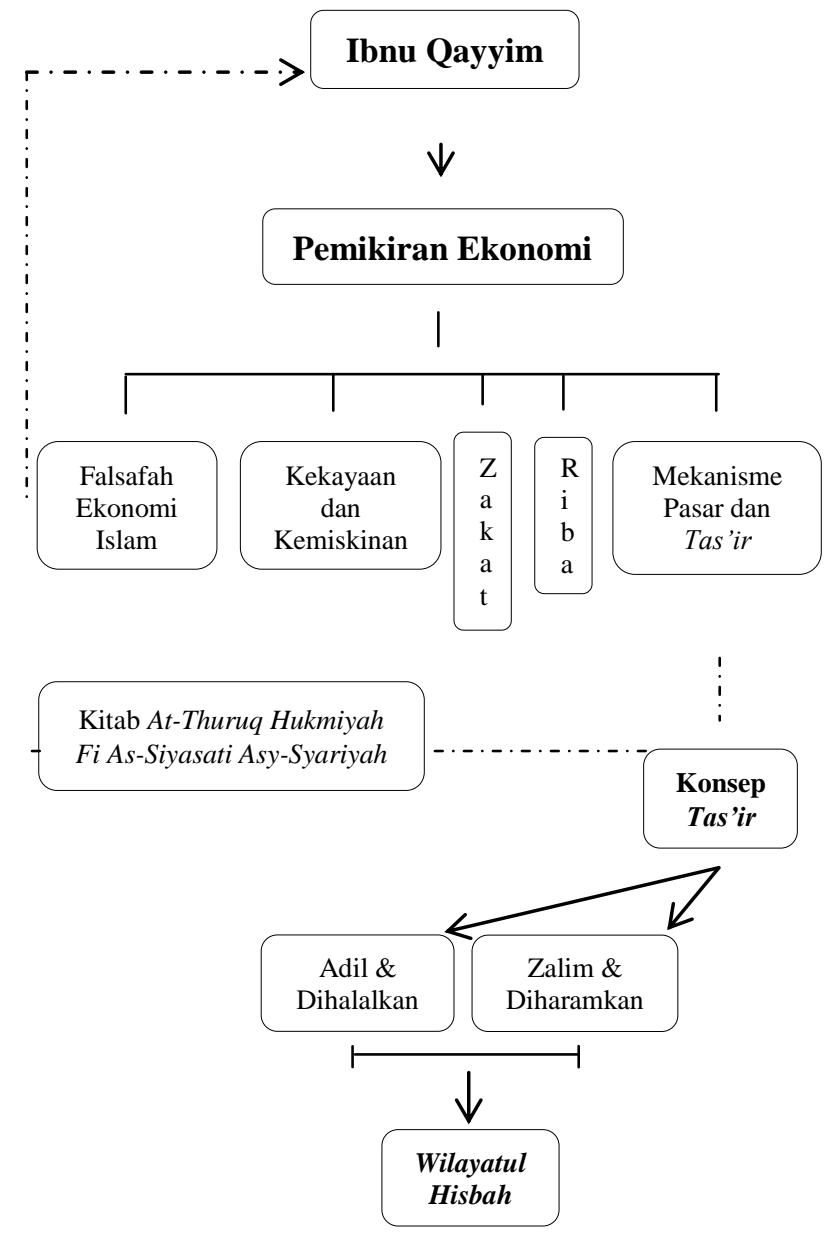

Gambar 1 Kerangka Pemikiran Ibnu

$$
\text { Qayyim }
$$

\section{Konsep Tas'ir dalam Kitab Al- Thuruq Hukmiyah fi A-Siyasati Al- Syariyah}

Tas'ir menurut bahasa sama dengan si'r yaitu menetapkan atau menentukan harga. ${ }^{20}$ Dapat juga dikatakan bahwa alsi'r adalah harga dasar (price rate), yang berlaku di kalangan pedagang. ${ }^{21}$ Dalam terminologi fikih, terdapat beberapa ungkapan yang menjelaskan pengertian tas'ir ini. Al-Syaukani menyatakan bahwa tas'ir adalah perintah penguasa atau wakilnya atau perintah setiap orang yang mengurus urusan kaum muslimin kepada para pedagang untuk tidak menjual barang dagangannya kecuali dengan harga yang telah ditetapkan, dilarang untuk menambah atau menguranginya dengan tujuan untuk kemaslahatan.

Menurut Ibnu Qayyim penggolongan tas'ir dibagi kedalam 2 bagian yakni: tas'ir yang zalim yang diharamkan dan tas'ir adil yang dihalalkan. Tas'ir diharamkan apabila mengandung unsur menzalimi manusia dan memaksa mereka dengan cara yang tidak benar agar menjual barang dengan harga yang tidak mereka setujui atau melarang mereka melakukan sesuatu yang dibolehkan oleh Allah. Tas'ir dibolehkan bahkan diwajibkan jika mengandung unsur keadilan, misalnya memaksa masyarakat melakukan akad tukar menukar dengan harga normal dan melarang mereka mengambil tambahan dari harga normal. ${ }^{22}$ 
Penerapan harga yang adil dalam mekanisme pasar menjadi pegangan yang mendasar dalam transaksi yang Islami. Pada prinsipnya transaksi bisnis dilakukan pada harga yang adil karena merupakan cerminan dari komitmen syariat Islam terhadap keadilan yang menyeluruh. Secara umum, harga yang adil ini adalah harga yang tidak menimbulkan eksploitasi atau penindasan/kezhaliman sehingga merugikan salah satu pihak. Misalnya, harga yang lebih tinggi daripada yang seharusnya akan merugikan pembeli, dan harga yang terlalu rendah justru akan merugikan penjual. Penetapan harga/ tas'ir dilakukan untuk mengendalikan harga menuju harga yang adil. Sehingga harga harus mencerminkan manfaat bagi pembeli dan penjual secara adil yaitu penjual memperoleh keuntungan normal dan pembeli memperoleh manfaat setara dengan harga yang dibayarkan.

Adapun contoh tas'ir yang dilarang disebutkan dalam hadits riwayat Anas yang mengatakan bahwa "harga meninggi di zaman Nabi Muhammad." Masyarakat berkata kepada Nabi “wahai Rasulullah, berkenankah engkau menetapkan harga untuk kami?" Rasulullah bersabda,

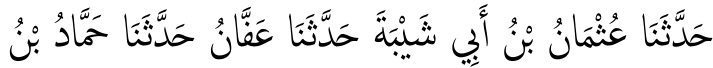

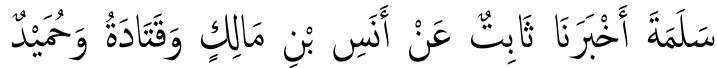

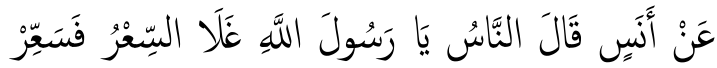

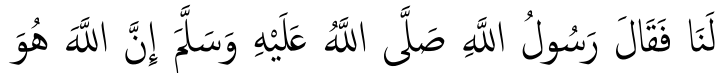

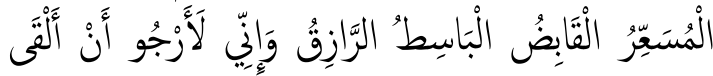

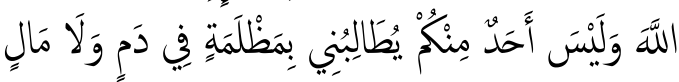
Artinya:

"Telah menceritakan kepada kami Utsman bin Abu Syaibah?, telah menceritakan kepada kami 'Affan, telah menceritakan kepada kami Hammad bin Maslamah, telah mengabarkan kepada kami Tsabit dari Anas bin Malik dan Qatadah, serta Humaid dari Anas, orang-orang berkata; wahai Rasulullah, harta telah melonjang, maka tetapkanlah harga untuk kami! Maka beliau berkata: "Sesungguhnya Allahlah yang menentukan harga, Yang menggenggam dan Yang menghamparkan, dan Pemberi rizqi. Dan sungguh aku berharap berjumpa dengan Allah sementara tidak ada seorang pun dari kalian yang menuntutku karena suatu kezhaliman dalam hal darah, dan harta." (HR. Abu Daud No. 2994)

Adakalanya masyarakat menjual barang dagangan dengan cara ma'ruf tanpa melakukan kezaliman. Namun, saat itu harga melambung karena langkahnya stok barang, juga karena banyaknya konsumen yang membutuhkan. Ini adalah 
kehendak Allah, dalam keadaan seperti ini mewajibkan masyarakat untuk menjual barangnya dengan harga tertentu sama saja memaksa mereka dengan cara yang tak benar.

Adapun contoh tas'ir yang diperbolehkan menurut Ibnu Qayyim yakni seperti pemilik barang menolak menjual barangnya, padahal masyarakat pada saat itu sangat membutuhkannya. Pemilik barang hanya mau menjual dengan syarat harga barangnya dinaikkan melebihi harga normal kala itu. Dalam keadaan seperti ini, pemilik wajib menjual barangnya dengan harga normal, melakukan tas'ir dalam konteks ini berarti memberikan keadilan bagi semua yang mana keadilan diwajibkan oleh Allah. $^{23}$

Ibnu Qayyim juga memandang bahwa penguasa wilayatul hisbah dalam konteks saat ini adalah pemerintah mewajibkan masyarakat agar tidak menjual bahan makanan atau barang lain kecuali kepada orang-orang umum yang dikenali, kemudian orang-orang itu menjualnya lagi dengan harga yang mereka inginkan. Jika masyarakat menjual kepada selain orang-orang tersebut, maka pelakunya harus dilarang dan dihukum bila melanggar larangan tersebut, karena perbuatan tersebut merupakam kezhaliman yang menghalangi tetesan rezeki dari Allah swt.

Al-Mawardi mendefiniskan wilayatul hisbah sebagai lembaga yang berfungsi untuk memerintahkan kebaikan sehingga menjadi kebiasaan dan melarang hal yang buruk ketika hal itu telah menjadi kebiasaan umum. Sedangkan Muhammad al-Mubarak menyatakan bahwa wilayatul hisbah merupakan fungsi kontrol pemerintah melalui kegiatan perorangan yang khususnya memiliki garapan bidang moral, agama, dan ekonomi. ${ }^{24}$

Jadi, wilayatul hisbah merupakan sebuah lembaga yang berfungsi untuk mengontrol pasar dan moral para pelaku pasar secara umum, sebagai bentuk regulator, mengawasi, dan mengatur mekanisme pasar agar berjalan seimbang sehingga tercipta harga yang adil ini salah satu bentuk peran pemerintah melakukan intervensi/ campur tangan dengan melakukan regulasi harga untuk kemaslahatan pemenuhan kebutuhan 
dasar dan memelihara kejujuran para pelaku pasar.

Hal ini telah diungkapkan dalam penelitian sebelumnya yakni oleh Euis Amalia ${ }^{25}$ mengungkapkan bahwa konsep ekonomi Islam menegaskan bahwa mekanisme pasar dan penetapan harga perlu diatur untuk menegakkan keseimbangan pasar dan keadilan ekonomi dengan mempertimbangkan kepentingan para pihak yang terlibat di pasar. Harga wajar dan adil (fair price) adalah harga yang diperoleh berdasarkan kekuatan penawaran (supply) dan permintaan (demand). Manakala terjadi tindakan-tindakan yang bersifat zalim sehingga terjadi distorsi pasar atau harga tidak berada pada titik keseimbangannya, pemerintah sangat berperan untuk mengambil kebijakan berupa penetapan harga dengan melihat faktor-faktor penyebab terjadinya distorsi tersebut dan mengembalikan harga pada titik keseimbangannya semula. Keseimbangan ekonomi dalam sistem ekonomi Islam akan terbentuk lebih pada keseimbangan sektor riil, bukan berarti mengabaikan sektor moneter, tetapi karena memang karakteristik perekonomian Islam adalah perekonomian riil sehingga keseimbangan ekonomi murni terjadi akibat kesesuaian permintaan dan penawaran dalam pasar. Sementara yang menjadi definisi sektor moneter dalam Islam lebih pada aktivitas investasi dan pengelolaan uang beredar. Keseimbangan ini terlihat pada gambar siklus ekonomi yang merujuk pada aktivitas yang sesuai dengan prinsip dan aturan syariah. Para pemikir Islam pada masa awal dan pertengahan telah merumuskan dengan sangat komprehensif tentang makna keadilan dalam hal harga dan juga kebijakan ekonomi yang sangat relevan dengan kondisi saat ini.

Penelitian Marhamah Saleh $^{26}$ mengungkapkan bahwa mekanisme pasar yang sesuai dengan syariah memang tidak mengedepankan intervensi pemerintah pada kondisi pasar berjalan normal. Namun, ketika pasar mengalami distorsi yang disebabkan oleh ulah para pelakunya, maka pemerintah tentu perlu turun tangan membenahi persoalan harga tersebut, sesuai dengan misi yang diemban untuk mewujudkan kemaslahatan umat. Intervensi pasar dan regulasi harga dalam Islam dimaksudkan agar tercipta keseimbangan harga dan 
terjaganya hak dari semua pihak, baik pembeli maupun penjual. Untuk itu perlu ditekankan aspek moralitas yang berdampingan dengan motif mencari laba dalam perniagaan. Hal penting dari persoalan regulasi adalah komitmen Islam dalam menegakkan aturan-aturan dengan memberlakukan institusi hisbah, yang memiliki tanggungjawab dan wewenang dalam pengawasan pasar, bahkan lembaga hisbah atau wilayat al-hisbah dapat berlaku pada persoalan-persoalan lain yang lebih universal, seperti kesejahteraan, terpenuhinya fasilitas umum dan terjaganya hukum. Secara komparatif, para ulama terdahulu telah menyumbangkan pemikirannya dalam membahas mekanisme pasar dan keseimbangan harga. Dunia pasar adalah suatu indikator pekermbangan ekonomi. Menurut konsep ekonomi modern, mekanisme pasar diatur melalui adanya pemenuhan barang dan keperluan akan barang tersebut. Namun demikian, jauh sebelum itu, ulama seperti Abu Yusuf, Yahya Ibn Umar, al-Gazali, Ibnu Taymiyyah, Ibnu Khaldun, Ibnu Qayyim telah memberikan pandangan mereka tentang mekanisme pasar dan kebijakan pemerintah dalam mengatur pasar dan harga-harga barang. Sebaliknya, dalam situasi yang normal saat ini, pemerintah tidak melakukan intervensi dalam penentuan harga barang dan mekanisme pasar. Akan tetapi ketika praktik kecurangan terjadi dalam transaksi pasar misalnya monopoli maka pemerintah sangat perlu untuk mengontrol harga demi kepentingan masyarakat.

Hal yang sama juga diungkapkan oleh Qusthoniah ${ }^{27}$ bahwa penetapan harga pada suatu perdagangan dan bisnis diperbolehkan jika di dalamnya terdapat kemungkinan adanya manipulasi sehingga berakibat naiknya harga. Berbagai macam metode penetapan harga tidak dilarang oleh Islam dengan ketentuan yakni harga yang ditetapkan oleh pihak pengusaha/ pedagang tidak menzalimi pihak pembeli yaitu tidak dengan mengambil keuntungan di atas normal atau tingkat kewajaran. Tidak ada penetapan harga yang sifatrnya memaksa terhadap para pengusaha/ pedagang selama mereka menetapkan harga yang wajar. Harga disenangi oleh masingmasing pihak, baik pihak pembeli maupun penjual. Harga merupakan titik 
keseimbangan antara kekuatan permintaan dan penawaran pasar yang disepakati secara rela sama rela oleh pembeli dan penjual. Apabila keseimbangan ini terganggu, maka pemerintah harus melakukan intervensi ke pasar dengan menjunjung tinggi asasasas keadilan baik terhadap pihak pedagang maupun terhadap pihak konsumen.

Penetapan harga yang adil oleh pemerintah sangat diajurkan ketika situasi dalam pasar mengalami kekacauan sehingga menimbulkan mudarat bagi pelaku pasar. Hal itu yang menjadi peran pemerintah sebagai wilayatul hisbah dalam intervensi persoalan harga yang berlaku dalam pasar.

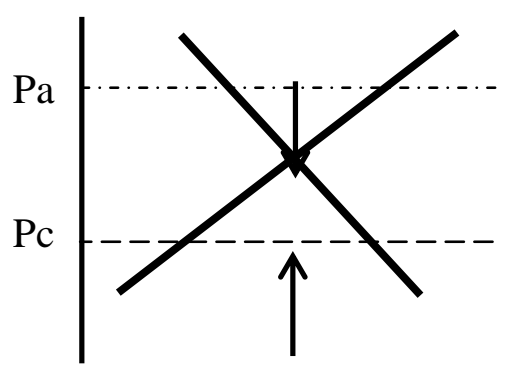

$\mathrm{Pb}$

\section{Gambar 2 Intervensi Harga oleh}

Jika melihat gambar tersebut dapat disimpulkan bahwa jika intervensi harga oleh pemerintah pada posisi diatas atau dibawah harga pasar/ harga umumnya yang terjadi dalam situasi normal, maka disebut intervensi yang zhalim dan tidak sah jika berada pada titik $\mathrm{Pa}$ atau $\mathrm{Pb}$. Intervensi harga oleh pemerintah dilakukan justru untuk mengembalikan harga pada posisi harga umum/lazim atau harga pasar sehingga menciptakan keadilan bagi penjual dan pembeli jika berada pada titik Pc dengan menekankan pada penetapan harga dilakukan dengan musyawarah yang melibatkan pihakpihak yang terkait dengan pasar. Intervensi ini dilakukan jika harga sedemikian tinggi diluar kewajaran sehingga tidak terjangkau oleh masyarakat, terjadinya ketidakadilan atau eksploitasi antara pelaku pasar, menyangkut barang-barang yang amat dibutuhkan oleh masyarakat, sedangkan penjual tidak mau menjualnya. Misalnya, kebutuhan pangan (beras, gula, minyak, dan lainnya), gas elpiji, bahan bakar minyak, dan sebagainya. Sehingga tujuan pemerintah (wilayatul hisbah) untuk 
mewujudkan harga yang berkeadilan bagi semua pihak (penjual dan pembeli).

Namun hal tersebut jauh sebelumnya telah diungkapkan oleh Ibnu Qayyim, dimana wilayatul hisbah (dalam hal ini pemerintah) dalam pandangan Ibnu Qayyim bertugas menegakkan amar ma'ruf nahi munkar dalam kasus-kasus yang bukan wewenang para wali, qadi, ahli dewan, dan lainnya. Penguasa wilayatul hisbah memerintahkan rakyatnya untuk senantiasa taat dalam ibadah, bersifat amanah dan shidiq, baik dalam ucapan dan perbuatan. Penguasa wilayatul hisbah melarang rakyat berbuat khianat, mengurangi timbangan, dan curang dalam jual beli.

Penguasa wilayatul hisbah bertugas mengawasi keakuratan alat timbangan, mengawasi para produsen untuk tidak curang, zalim dan melanggar etika produksi dalam Islam (dilarang memproduksi barang yang diharamkan), mengawasi agar rakyat tidak mengkomsumsi hal yang diharamkan, mengawasi agar uang tidak rusak dan diubah, mengawasi agar uang tidak dijadikan barang yang diperdagangkan, sehingga uang hanya digunakan sebagai alat tukar jual beli barang. ${ }^{28}$

Prinsip utama wilayatul hisbah adalah memberantas para penipu/pemalsu dan para pezhalim/ oknum curang, dan bentuk-bentuk perbuatan munkar terkait dengan transaksi bisnis demi terwujudnya kemaslahatan umat.

Penguasa wilayatul hisbah wajib menetapkan harga barang-barang yang dijual oleh orang-orang tersebut. Mereka hanya boleh menjual dan membeli barang dengan harga standar atau umumnya yang berlaku. Pendapat ini tidak diragukan oleh seorang ulama manapun, dikarenakan jika orang umum dilarang menjual dan membeli, lalu orang tertentu diberi hak menjual dan membeli dengan harga yang ditentukan sendiri, maka ini adalah sebuah kezhaliman pada masyarakat umum, kezhaliman kepada penjual yang menjual barang kepada orang tertentu dan kezhaliman kepada masyarakat lain yang membelinya. Tas 'ir dalam bentuk tersebut adalah wajib dan tidak ada seorangpun yang membantah hal ini.

Hakikat tas'ir adalah mewajibkan pelaku pasar untuk bertindak adil dan 
mencegahnya melakukan kezhaliman. Tidaklah dibolehkan memaksa (dengan cara yang tidak benar) orang untuk membeli. Demikian pula, boleh atau wajib memaksa (dengan cara yang benar) orang membeli dengan cara yang benar, misalnya memaksa yang dibolehkan menurut Ibnu Qayyim adalah memaksa orang menjual barang untuk membayar hutang yang wajib dilunasinya, memaksa seseorang menjual makanan kepada orang yang sangat membutuhkan. ${ }^{29}$

Menurut Ibnu Qayyim dalam masalah tas'ir $^{30}$ para ulama berbeda pendapat pada 2 poin yakni jika ada barang yang sudah berlaku umum, kemudian ada sebagian orang yang ingin menjual barangnya dengan harga di atas harga umum itu, maka hukumnya menurut Malik, hal ini dilarang. Hukum menjual dengan harga dibawah harga umum, ada dua pendapat untuk menjawab hal tersebut. Malik berargumentasi dengan hadits dalam Al-Muwatha' dari Yunus bin Saif, dari Sa'id bin AlMusayyib. Disebutkan bahwa Umar bin Al-khathab berpapasan dengan Hathib bin Abu Balta'ah. Hathib saat itu menjualkan anggur kering milik Umar. Umar berkata kepadanya, "Kau tambah harganya, atau kalau tidak kau tinggalkan saja pasar kami."

Malik berkata, "jika seorang lelaki ingin merusak pasar dan menjual dengan harga di bawah harga umum, maka aku berpendapat untuk mengatakan kepadanya, kau jual dengan harga uтum atau kalau tidak kau tinggalkan saja pasar kami," ada yang mengatakan kepada orang-orang di pasar, "jangan kau jual kecuali dengan harga sekian." Ucapan itu tidaklah benar". Kemudian dia menyebutkan hadits Umar bin Abdul Azis terkait dengan penduduk Ubullah saat barang-barang turun karena adanya gangguan cuaca di laut. Umar bin Abdul Azis berkata, "biarkan saja terjadi harga secara alamiah, sesungguhnya harga itu ada dalam kuasa Allah.”

Ibnu Rusyd dalam kita Al-Bayan mengatakan, "tiada yang menyanggah bahwa harga yang dijual oleh pedagang yang menjual dagangannya di atas harga umum, maka kepadanya dikatakan, "kau jual dengan harga umum, atau kalau tidak kau boleh tinggalkan pasar ini." Hal ini dilakukan oleh Umar bin AlKhatab terhadap Hathib bin $\mathrm{Abu}$ 
Balta'ah. Kala itu Umar berpapasan dengan Hathib yang sedang menjual anggur kering, dikarenakan saat itu Hathib menjual barangnya dengan harga satu dirham lebih murah daripada harga yang berlaku dipasar.

Ada kalanya pemilik toko atau pasar membeli daging, lauk-pauk, buahbuahan dari pedangan lain secara grosir, lalu mereka menjualnya kembali secara eceran. Menurut satu pendapat, pedagang seperti ini statusnya sama dengan pedagang lainnya. Mereka tidak dipaksa untuk menjual dagangannya dengan harga tertentu. Hanya saja, apabila ada pedagang yang menjual dengan harga yang jauh dari harga pasar, maka dikatakan kepada mereka, "jual dengan harga umum, atau tinggalkan saja pasar ini. " Inilah pendapat Malik dalam riwayat ini.

Sebuah pendapat lain mengatakan bahwa "Pedagang yang membeli secara grosir kemudian menjualnya secara eceran berbeda dengan pedagang lainnya, mereka tidak dibiarkan menentukan harga sendiri jika mereka menjual mahal kepada masyarakat dan tidak puas dengan keuntungan yang standar."

Wilayatul hisbah atau dalam hal ini pengurus pasar wajib mengetahui harga grosir yang diterima oleh para pedagang eceran, lalu pengurus pasar menetapkan keuntungan yang layak diterima oleh pedagang eceran tersebut. Pengurus pasar mencegah agar para pedagang eceran itu tidak mendapatkan keuntungan yang melebihi sewajarnya. Pengurus pasar harus selalu mengecek perkembangan pasar, dan melarang para pedagang mengambil keuntungan melebihi keuntungan. Pengurus pasar wajib menghukum pedagang yang melanggar ketentuan ini dan mengusirnya dari pasar. Ini adalah pendapat Malik dalam riwayat Asyhab.

Tak satu pun ulama membolehkan pengurus pasar berkata kepada pedagang, “jangan kalian menjual kalian menjual dengan harga sekian-sekian, baik kalian untung atau rugi!'tanpa mempertimbangkan dengan harga berapa para pedagang itu berkulakan. Ulama juga melarang berkata kepada pedagang, "jangan menjual barang ini kecuali dengan harga sekian dan sekian dengan 
harga standar atau kurang dari harga standar".

Jika para pedagang itu mendapatkan keuntungan, maka pengurus pasar tidak boloeh membiarkan mereka menaikkan harga saat membeli barang kulakan, meski tidak mendapat keuntungan melebihi dari ketentuan yang ditetapkan, karena mereka akan menunda-nunda pembelian barang kulakan jika mereka tahu pasti akan selalu untung.

Al-Syafi'i menolak pendapat ini dengan argumentasi hadits yang diriwayatkan dari Ad-Darawardi, dari Daud bin Salih At-Tammar, Ari al-Qasim bin Muhammad dari Umar, disebutkan Umar berpapasan dengan dengan Hathib bin Abu Balta'ah di pasal al-Mushalla kala itu ia membawa dua wadah berisi anggur kering, kemudian Umar menanyakan anggur tersebut. Hathib mengatakan, "perdua mudd harganya satu dirham". Umar kemudian berkata kepada Hathib,"Aku diberi tahu satu rombongan datang dari Thaif, mereka membawa dagangan anggur kering, mereka tertarik dengan harga yang kau tawarkan, kau harus menaikkan hargamu. Jika kau tak mau, masukkan saja anggur keringmu ke dalam rumahmu, dan jual anggurmu dengan harga sesukamu." Setelah pergi Umar merenungkan apa yang dikatakannya kemudian ia menemui Hathib dan berkata, "apa yang baru saja ku katakan padamu bukanlah keputusanku itu ku katakana demi kebaikan kota ini. Jual daganganmu sesukamu dan jual daganganmu bagaimanapun cara yang kau suka."

Al-Syafi'i berkata, 'Ini adalah hadits mustafidh, tidak bertentangan dengan hadits yang diriwayatkan oleh Malik. Hanya saja Malik meriwayatkan sebagian hadits, atau perawi lain meriwayatkan dari Malik, dan perawi ini menyebutkan awal dan akhir hadits, dan riwayat inilah yang aku pakai, karena semua manusia itu diberi kuasa terhadap harta miliknya. Tidak ada orang lain yang boleh mengambil harta tersebut tanpa kerelaan dari yang punya."

Abu al-Walid al-Baji berkata dengan dasar pendapat Malik,"yang diperintahkan kepada pedagang yang menurunkan harga adalah menjual dagangannya dengan harga yang diterapkan oleh orang pada umumnya, 
jika ada pedagang yang menentukan harga lain, maka dia dipaksa untuk menerapkan harga yang berlaku umum. Kalau dia tidak mau maka dia dilarang berjualan. Jika ada pedagang yang menaikkan harga, maka pedagang lain tidak boleh dipaksa untuk mengikuti harga yang ditetapkan oleh pedagang tersebut, karena yang dipertimbangkan adalah harga umum dan harga umum itulah yang dijadikan patokan."

Menurut Ibnu Qayyim tentang hukum orang yang menaikkan harga diperlakukan sama dengan orang yang menaikkan harga dengan mengutip pendapat Ibnu al-Qishar al-Maliki mengatakan," Para sahabat kami berbeda pendapat dalam memahami pendapat Malik menurut para ulama Bagdad, man hatha si'ran berarti orang yang ingin menjual dengan harga lima dirham, sementara orang menjual dengan barang yang sama dengan harga delapan dirham. Menurut ulama Basrah, itu berarti orang yang ingin menjual dengan harga delapan dirham sementara orang menjual dengan barang yang sama dengan harga lima dirham, tindakan mereka itu bisa merusak pasar yang akan menyebabkan permusuhan dan keadaan ini akan menyebabkan ketidakstabilan pasar dan semua orang tidak mendapat kemashlahatan."

Dalam kitab Muhammad, disebutkan "Seorang pedagang tidak dilarang menjual dengan harga di bawah harga umum." Ibnu Hubaib mengatakan,"barang dagangan selain gandum harus dijual dengan harga pasar, jika tidak pedagang akan diusir dari pasar. Adapun menjual gandum maka dia boleh menjual dengan harga yang dia sukai. Hanya saja dia akan berhadapan dengan hukum pasar yakni sebagian pedagang lain menjual murah maka yang menjual mahal akan ditinggalkan konsumen. Jika sebagian besar pedagang menjual dengan harga murah maka kepada sebagian kecil yang menjual mahal diharuskan untuk menjual dengan harga yang sama jika tidak mereka akan diusir dari pasar."

Ibnu Hubaib mengatakan, "ketentuan ini berlaku pada barang yang bisa ditimbang, baik barang berupa makanan maupun bukan. Ketentuan ini tidak berlaku pada barang yang tidak bisa ditimbang karena harga barang 
tersebut tidak bisa distandarkan karena tiadanya kemiripan pada barang tersebut."

Abu al-Walid mengatakan,"jika kualitas barang berbeda maka penjual yang memiliki kualitas baik tidak diperintahkan untuk menjual barangnya dengan harga murah."

Masalah kedua yang diperselisihkan ulama tentang perlunya tas'ir dalam batasan harga yang tidak boleh dilanggar oleh para pedagang neski mereka telah menunaikan kewajibannya. Jumhur ulama bahkan imam Malik melarang hal tersebut. Pendapat malik tentang pengurus pasar yang menetapkan harga bagi pedagang daging, jika para pedagang daging itu menolak harga yang ditetapkan maka pedagang daging tersebut akan dikeluarkan dari pasar. Terkait hal itu Malik mengatakan, "Jika pengurus pasar menetapkan harga tersebut sesuai dengan harga yang pantas maka hal itu boleh dilakukan, tetapi pengurus pasar tidak boleh memaksa untuk meninggalkan pasar."

Tindakan tersebut dilakukan demi kemashlahatan agar harga tidak melambung. Tujuannya bukan untuk melarang menjual dagangannya tetapi mencegah mereka menjual melebihi batasan harga yang ditetapkan oleh pemerintah, yang mana poenetapan itu mengacu pada kemashlahatan bersama bagi penjual dan pembeli.

\section{Kriteria Tas'ir dalam Kitab Al- Thuruq Hukmiyah fi a-Siyasati al- Syariyah}

Menurut Ibnu Qayyim terkait dengan kriteria tas' $^{\prime}{ }^{31}$ pemerintah seharusnya mengumpulkan para tokoh pasar dan juga pihak lain, untuk mengetahui tingkat kejujuran mereka dalam pertemuan itu pemerintah menanyakan beberapa hal, misalnya cara berkulakan dan cara menjual dagangannya. Kemudian pemerintah menetapkan kebijakan yang membawa keuntungan bagi pedagang dan pembeli supaya para pedagang itu dengan lapang dada/bukan karena terpaksa menerima harga yang ditetapkan pemerintah. Disinilah pemerintah menjadi mediator yang menengahi kepentingan pedagang dan pembeli. Pemerintah menetapkan keuntungan yang pantas untuk para pedagang, tanpa mengorbankan kepentingan masyarakat umum. Jika 
pemerintah menetapkan harga yang dikehendaki oleh pedagang, yang tak mendatangkan keuntungan bagi mereka, maka ketetapan itu akan merusak harga, menghilangkan bahan makanan dari peredaran dan merusak peredaran uang.

Adapun jika para pedagangan enggan menjual barang yang seharusnya dijual, maka mereka boleh dipaksa untuk menjual barang dagangannya. Jika mereka tidak memahtuhinya maka mereka boleh dihukum. Para pedagang juga boleh dihukum jika menolak menjual dengan harga standar.

Adapun persoalan hadits Rasulullah menyangkut pengharaman tas'ir sebagaimana sabda Rasulullah, "Sesungguhnya Allahlah yang menentukan harga yang menyempitkan dan melapangkan rejeki, memberi rejeki sekaligus penentu harga dan sesungguhnya aku berharap bisa menemui Allah dan tidak ada seorang pun diantara kalian yang menuntutku atas suatu kedzaliman yang aku lakukan kepadanya, baik itu menyangkut darah ataupun harta." Dari hadits ini disimpulkan bahwa yang dapat melakukan tas'ir hanya Allah. Namun konteks hadits ini menyangkut masalah khusus tidak umum sifatnya. Dalam hadits ini tidak ada klausul yang menyebutkan kasus adanya pihak yang menolak menjual barang yang menjadi kebutuhan pokok masyarakat. Sudah diketahui jika suatu barang jumlahnya terbatas maka masyarakat cenderung ingin memilikinya dalam jumlah yang lebih. Jika produsen bisa mencukupi permintaan masyarakat maka tak perlu dilakukan tas'ir.

Menurut Mannan, Siddiqi dan Khaf menafsirkan hadits tersebut sebagai indikator perekonomian pasar bebas, dengan negara dipercaya untuk menjalankan fungsi yang semestinya yakni suatu pasar yang bebas dari segala bentuk manipulasi. ${ }^{32}$

Sehingga persoalan besar yang menunggu penyelesaian negara adalah terciptanya suatu pengaturan institusional yang jelas berdasarkan prinsip-prinsip Islam yang secara otomatik akan mengurusi semua penyakit ekonomi masyarakat. Artinya bagaimana pun peran negara sangatlah krusial untuk menjaga stabilitas harga yang berkeadilan yang melindungi kepentingan masyarakat luas 
dengan menerapkan teori harga Islami yang melarang setiap bentuk manipulasi/pemerasan, baik dari pihak penjual dan pembeli. Dikarenakan bentuk manipulasi/ pemerasan dalam mekanisme pasar dalam Islam merupakan perbuatan tercela, bukan saja pada dimensi duniawi tapi juga bentuk ukhrawi.

Sehingga dapat disimpukan bahwa untuk lebih menjamin berjalannya mekanisme pasar secara sempurna, peranan pemerintah sangat penting. Rasulullah sendiri telah menjalankan fungsi sebagai market supervisor atau wilayatul hisbah yang kemudian banyak banyak dijadikan acuan untuk peran negara terhadap pasar untuk mewujudkan harga yang wajar lagi adil.

\section{PENUTUP}

\section{A. Kesimpulan}

Ibnu Qayyim al-Jauziyyah adalah seorang ulama jenius yang berwawasan global, beliau merupakan seorang pemikir Islam, ahli sejarah dan fiqh yang handal, memiliki keaslian analisa serta ijtihad dan fatwa yang cemerlang. Ibnu Qayyim salah seorang ulama salaf yang bisa diterima banyak kalangan, karna itu karya-karyanya terus dicari oleh para penuntut ilmu. Beliau merupakan murid dari Ibnu Taimiyah yang dikenal dengan berbagai macam pemikiran ekonominya seputar persoalan makro ekonomi seperti harga yang adil, mekanisme pasar, regulasi harga, uang dan kebijakan moneter.

Ibnu Qayyim dalam kitab al-Thuruq Hukmiyah fi al-Siyasati al-Syariyah membagi tas'ir menjadi dua bagian yakni tas'ir yang adil dan dihalalkan dan juga tas'ir yang zalim dan diharamkan. Penetapan harga/tas'ir yang adil dalam mekanisme pasar telah menjadi pegangan yang mendasar dalam setiap transaksinya. Penetapan harga yang adil oleh pemerintah sangat diajurkan ketika situasi dalam pasar mengalami kekacauan sehingga menimbulkan mudarat bagi pelaku pasar. Hal itu yang menjadi peran pemerintah sebagai wilayatul hisbah dalam menetapkan harga yang berlaku dalam pasar demi terwujudnya kemaslahatan sesuai dengan konsep Islam yang menegaskan pasar harus berprinsip persaingan sempurna/ perfect competition dengan kebebasan yang dibungkus oleh kerangka syariah dengan membangun 
prinsip freedom contract/ arrida/kerelaan (antaradim minkum), fair competition/persaingan sehat, honesty/ kejujuran, transparency/ keterbukaan, dan justice/keadilan. 


\section{Daftar Pustaka Bibliography}

Al-Jamal, M. Hasan. Biografi 10 Imam Besar. Jakarta: Pustaka Al-Kautsar, 2006.

Al-Jauziyyah, Ibnu Qayyim, Ath-Thuruq Al-Hukmiyyah fi As-Siyasah AsySyar'iyyah (Beirut: Darul Jael, 1998), diterjemahkan oleh Muhammad Muchson Anasy. Jakarta: Pustaka Al-Kautsar, 2014.

Al-Jauziyyah,Ibnu Qayyim At-Thuruq Hukmiyah Fi As-Siyasati AsySyariyah. Bairut: Darul Jael, 1418 H/1998 M.

Amalia, Euis. Jurnal dengan judul "Mekanisme Pasar dan Kebijakan Penetapan Harga dalam Perspektif Ekonomi Islam” Jurnal Al-Iqtishad, Vol.5, No. 1 (2013).

Azwar, Saefuddin. Metode Penelitan. Yogyakarta: Pustaka Pelajar, 1998.

Borhan, Joni Tamkin Bin (Universiti Malaya), Jurnal dengan judul "Pemikiran Ekonomi Ibnu Qayyim Al-Jauziyyah” Jurnal Usuluddin Bil 25, (2007).

Dahlan, Abdul Aziz. Ensklopedi Hukum Islam. Jakarta: PT.Ichtiar Baru, 1997.

Djakfar, Muhammad. Agama Etika dan Ekonomi. Malang: UIN-Maliki Press, 2014.

Faizal, Moh. dan Havis Aravik, Islam Rahmatan Lil Alamin. Palembang: Noer Fikri Offset, 2015

Haneef, Muhammed Aslam. Pemikiran Ekonomi Islam Kontemporer. Jakarta: Rajawali Pers, 2010.

Irawan, Toni. Jurnal dengan judul "Pemikiran Ekonomi Ibnu AlQayyim” Jurnal Iqtishodia Ekonomi Islam Republika, (2010).
Karim, Adiwarman Azwar. Sejarah Pemikiran Ekonomi Islam. Yogjakarta: IIIT, 2001.

Mardani, Ayat-ayat dan Hadis Ekonomi Syariah. Jakarta: Rajawali Pers, 2011.

P3EI. Ekonomi Islam. Jakarta: Rajawali Pers, 2008.

Perwataatmadja, Karnaen A \& Anis Byarwati, Jejak Rekam Ekonomi Islam. Jakarta: Cicero Publishing, 2008.

Qusthoniah, Jurnal dengan judul “Tas'ir al-Jabari (Penetapan Harga oleh Negara) dalam koridor Fiqh dengan Mempertimbbangkan Realitas Ekonomi" Jurnal Syariah, Vol.2, No. 2 (2014).

Rawas, Muhammad dan Hamid Shadiq. Mu'jam al-Lughah al-Fuqaha. Bairut: Dar al-Nafais, 1985.

Rivai, H.Vethzal dan H.Andi Buchari, Islamic Economics; Ekonomi Syariah Bukan Opsi, tetapi Solusi. Jakarta: Bumi Aksara, 2009.

Rusdi, Muhammad Ali. "الفقر وعلاجه فى ) "تصور القران (دراسة لغوية تفسيرية Langkawi: Journal of The Association for Arabic and English 1.1 (2015).

Saleh, Marhamah. Jurnal dengan judul "Pasar Syariah dan Keseimbangan Harga" Jurnal Media Syariah, Vol.13, No. 1 (2011).

Siddiqi, Nejatullah The History of Islamic Economic Thought, Dalam Ausaf Ahmad dan Kazim Reza Awan, Lecture on Islamic Economics. Jeddah: IRTI IDB, 1992.

\footnotetext{
${ }^{1}$ Kegiatan ekonomi merupakan sesuatu yang tidak bisa dipisahkan dalam kehidupan manusia. Kegiatan yang berupa produksi, distribusi dan konsumsi ini dilakukan dalam rangka memenuhi seluruh
} 
kebutuhan hidup manusia. Setiap tindakan manusia didasarkan pada keinginannya untuk memenuhi kebutuhan hidupnya.

${ }^{2}$ P3EI, Ekonomi Islam (Jakarta: Rajawali Pers, 2008), h. 97.

${ }^{3}$ P3EI, Ekonomi Islam, h. 97.

${ }^{4}$ Nejatullah Siddiqi, The History of Islamic Economic Thought, Dalam Ausaf Ahmad dan Kazim Reza Awan, Lecture on Islamic Economics, (Jeddah: IRTI IDB, 1992), h. 71.

${ }^{5} \mathrm{P} 3 \mathrm{EI}$, Ekonomi Islam, h. 105.

${ }^{6} \mathrm{P} 3 \mathrm{EI}$, Ekonomi Islam, h. 109-110.

${ }^{7} \mathrm{P} 3 \mathrm{EI}$, Ekonomi Islam, h. 115.

${ }^{8}$ Karnaen A. Perwataatmadja \& Anis Byarwati, Jejak Rekam Ekonomi Islam (Jakarta: Cicero Publishing, 2008), h. 159.

${ }^{9}$ M. Hasan Al-Jamal, Biografi 10 Imam Besar (Jakarta: Pustaka Al-Kautsar, 2006), h. 229.

${ }^{10}$ Mardani, Ayat-ayat dan Hadis Ekonomi Syariah (Jakarta: Rajawali Pers, 2011), h. 198.

${ }^{11}$ Ibnu Qayyim Al-Jauziyyah, At-Thuruq Hukmiyah Fi As-Siyasati Asy-Syariyah (Bairut: Darul Jael, 1418 H/1998 M).

${ }^{12}$ Adiwarman Azwar Karim, Sejarah Pemikiran Ekonomi Islam (Yogjakarta: IIIT, 2001), h. 10.

${ }^{13}$ Penelitian pustaka atau library research adalah kegiatan yang meliputi mencari, membaca, dan menelaah laporan-laporan penelitian dan bahan pustaka yang memuat teori-teori yang relevan dengan penelitian yang dilakukan. Lihat: Saefuddin Azwar, Metode Penelitan (Yogyakarta: Pustaka Pelajar, 1998), h. 7.

${ }^{14}$ Moh. Faizal dan Havis Aravik, Islam Rahmatan Lil Alamin (Palembang: Noer Fikri Offset, 2015), h. 111.

${ }^{15}$ H.Vethzal Rivai dan H.Andi Buchari, Islamic Economics; Ekonomi Syariah Bukan Opsi, tetapi Solusi (Jakarta: Bumi Aksara, 2009), h. 391-397. Lihat juga

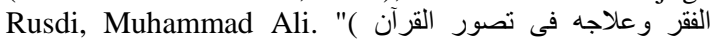
 Association for Arabic and English 1.1 (2015): 85-103.

${ }^{16}$ Muhammad Djakfar, Agama Etika dan Ekonomi (Malang: UIN-Maliki Press, 2014), h. 128.

${ }^{17}$ Muhammad Djakfar, Agama Etika dan Ekonomi, h. 129.

${ }^{18}$ Toni Irawan, Jurnal dengan judul "Pemikiran Ekonomi Ibnu Al-Qayyim” Jurnal Iqtishodia Ekonomi Islam Republika, (2010).

${ }^{19}$ Joni Tamkin Bin Borhan (Universiti Malaya), Jurnal dengan judul "Pemikiran Ekonomi Ibnu Qayyim Al-Jauziyyah" Jurnal Usuluddin Bil 25, (2007).

${ }^{20}$ Abdul Aziz Dahlan, Ensklopedi Hukum Islam (Jakarta: PT.Ichtiar Baru, 1997), h. 1802.

${ }^{21}$ Muhammad Rawas dan Hamid Shadiq, Mu'jam al-Lughah al-Fuqaha (Bairut: Dar al-Nafais, 1985), h. 244.

${ }^{22}$ Ibnu Qayyim Al-Jauziyyah, Ath-Thuruq AlHukmiyyah fi As-Siyasah Asy-Syar'iyyah (Beirut: Darul
Jael, 1998), diterjemahkan oleh Muhammad Muchson Anasy (Jakarta: Pustaka Al-Kautsar, 2014), h. 430.

${ }^{23}$ Ibnu Qayyim Al-Jauziyyah, Ath-Thuruq AlHukmiyyah fi As-Siyasah Asy-Syar'iyyah, h.431.

${ }^{24}$ P3EI, Ekonomi Islam, h. 342.

${ }^{25}$ Euis Amalia, Jurnal dengan judul "Mekanisme Pasar dan Kebijakan Penetapan Harga dalam Perspektif Ekonomi Islam" Jurnal Al-Iqtishad, Vol.5, No. 1 (2013).

${ }^{26}$ Marhamah Saleh, Jurnal dengan judul "Pasar Syariah dan Keseimbangan Harga" Jurnal Media Syariah, Vol.13, No. 1 (2011).

${ }^{27}$ Qusthoniah, Jurnal dengan judul "Tas'ir alJabari (Penetapan Harga oleh Negara) dalam koridor Fiqh dengan Mempertimbbangkan Realitas Ekonomi" Jurnal Syariah, Vol.2, No. 2 (2014).

${ }^{28}$ Ibnu Qayyim Al-Jauziyyah, Ath-Thuruq AlHukmiyyah fi As-Siyasah Asy-Syar'iyyah, h.423.

${ }^{29}$ Ibnu Qayyim Al-Jauziyyah, Ath-Thuruq AlHukmiyyah fi As-Siyasah Asy-Syar'iyyah, h.432.

${ }^{30}$ Ibnu Qayyim Al-Jauziyyah, Ath-Thuruq AlHukmiyyah fi As-Siyasah Asy-Syar'iyyah, h.445-451.

${ }^{31}$ Ibnu Qayyim Al-Jauziyyah, Ath-Thuruq AlHukmiyyah fi As-Siyasah Asy-Syar'iyyah, h. 451-452.

${ }^{32}$ Muhammed Aslam Haneef, Pemikiran Ekonomi Islam Kontemporer (Jakarta: Rajawali Pers, 2010), h. 165. 